\title{
Native and Non-Native Writers' Use of Stance Adverbs in English Research Article Abstracts*
}

\author{
Hamide Çakır \\ Department of Foreign Language Education, Niğde University, Niğde, Turkey \\ Email: hamide.cakir@nigde.edu.tr
}

Received 3 March 2016; accepted 10 April 2016; published 13 April 2016

Copyright (C) 2016 by author and Scientific Research Publishing Inc.

This work is licensed under the Creative Commons Attribution International License (CC BY).

http://creativecommons.org/licenses/by/4.0/

(c) (i) Open Access

\begin{abstract}
Stance in scientific writing has been a major focus of attention. However, studies on stance in the research article abstracts have been relatively scarce in Turkey compared to those in other academic prose. Abstracts contain various sections in which information on the purpose, method, results, and conclusions of the study is presented to promote the study and to attract readers' attention. In this respect, the abstract foregrounds the main findings and serves a promotional purpose (Hyland \& Tse, 2005). By comparing abstracts written by Turkish and native writers of English, this paper tries to explore how academic writers from different scientific communities construct author's stance in research article abstracts. In particular, the present study attempts to analyze lexico-grammatical features in research article abstracts focusing specifically on stance adverbs. Stance adverbs (clearly, probably, apparently) present the attitude or assessment of the speaker/writer with respect to the proposition (Biber, 2006). The corpus consists of 240 abstracts from the disciplines of sociology, psychology, linguistics, physics, chemistry and biology. The results revealed significant differences in the total number of stance adverbs. Native writers of English employed more stance adverbs in their abstracts than Turkish writers. Differences were also found of stance adverbs in soft and hard sciences. Academic writers in the soft sciences used more stance adverbs in their abstracts. Considering variations in scientific discourse across cultures and disciplines, the results of the study may have some pedagogical implications for academic writing courses.
\end{abstract}

\section{Keywords}

Stance Adverbs, Research Article Abstracts, Author's Stance, Scientific Discourse

\footnotetext{
${ }^{*}$ This article is a revised version of a paper presented at the Akdeniz Language Studies Conference.
} 


\section{Introduction}

Scientific discourse contains unique grammatical structures that construe scientific knowledge and reshape human experience (Halliday, 1994; Halliday \& Matthiessen, 1999). Studies analyzing the distinctive features of scientific discourse (e.g. Hyland, 1998, 2001, 2002; Hyland \& Tse, 2004; Swales, 1990, 2004) and the possible impact of language or discipline (e.g. Bazerman, 1985, 1988; Breivega et al., 2002; Dahl, 2004; Duszak, 1994; Mauranen, 1993; Moreno, 2004) have revealed that scientific language reflects the culture of the discourse community. To be precise, the cultural and social norms affect the way scientists reflect their world and the ways they develop logical reasoning. Each discourse community "employs its institutional discourse, its way of describing and categorizing a problem” (Reeves, 2005: p. 99). Taking this view, a large number of studies have been carried out on the research article (RA) focusing on its rhetorical and lexico-grammatical features (e.g. Hyland, 1996, 1999; Yakhontova, 2002; Chang \& Schleppegrell, 2011).

The great majority of the research articles (RAs) contain an informative abstract in which writers are expected to highlight the purpose, methodology, results, and conclusions of their study "to persuade readers that the article is worth reading” (Hyland, 2000: p. 64). Thus, abstracts involve rhetorical patterns (Hyland \& Tse, 2005), and they are "a valuable source for investigating the cultural causes and consequences of linguistic and rhetorical differences across languages” (Van Bonn \& Swales, 2007: p. 95). In this respect, although abstracts are still defined as “an accompany” (Swales \& Feak, 2009) of the RAs, it is one of the prerequisites of any RA which is to be published. Given this development, this part-genre has attracted considerable attention in recent years and studies on its rhetorical structure (e.g. Graetz, 1985; Swales, 1990; Salager-Meyer, 1992; Bhatia, 1993; Santos, 1996; Huckin, 2001; Lorés, 2004; Cross \& Oppenheim, 2006; Galebiowski, 2009) as well as contrastive studies focusing on discipline and/or culture (e.g. Ventola, 1994; Melander, Swales, \& Fredrickson, 1997; Hyland, 2000; Martín-Martín, 2002; Stotesbury, 2003; Martín-Martín \& Burgess, 2004; Yakhontova, 2002, 2006; Van Bonn \& Swales, 2007) have been carried out. These studies have found that writers' selective representation of their articles in the abstracts through various patterns of rhetorical moves is determined by how they think they can best convince others, especially members in their discipline, the value of their work, and that the general patterns of writers' choices often vary across disciplines (Hyland, 2000).

There have been numerous studies on scientific discourse in Turkey (e.g. Oktar, 1991; Huber \& Uzun, 2000; Uzun \& Huber, 2002; Yarar, 2001; Emeksiz, 2009, 2015; Doyuran, 2009; Kavanoz \& Şimşek, 2013; Akbaş, 2012b, 2014; Bayyurt \& Akbaş, 2014; Yağız \& Demir, 2014, 2015); however, compared to the vast number of studies in other countries, there are few studies on research article abstracts (Ekoç, 2008; Çakır, 2011; Akbaş, 2012a; Çandarlı, 2012; Çakır \& Kansu-Yetkiner, 2012; Fidan \& Çakır, 2012; Kafes, 2009, 2012; Uysal \& Akpınar, 2008; Önder Özdemir \& Longo, 2014; Uysal, 2014; Çakır \& Fidan, 2015; Uysal, 2012) written by Turkish academic writers. Kafes (2009) examined modal verbs in research articles as well as in abstracts written by Turkish, Spanish and American academic writers to determine how academic writers construct authorial stance in their research articles published in international journals. Kafes (2009) found similarities as well as some differences in the distribution of the modal verbs across the different parts in the research articles he examined. The findings indicated that writer stance in the research article is mainly guided by the norms of the international discourse community, but also by the local discourse community. Similarly, Uysal and Akpinar (2008) compared English abstracts written by different academic writers. The study examined indirectness markers (disclaimers, hedges and hedging devices, discourse particles, demonstratives and passive voice) in conference abstracts produced by Turkish and Indian academic writers. While Akbaş (2012a), Ekoç (2008) and Önder Özdemir \& Longo (2014) examined metadiscourse markers in abstracts, Çakır \& Fidan (2015) and Kafes (2012) focused on the rhetorical organization of abstracts. The findings of these studies revealed variations across abstracts.

In view of the fact that studies on abstracts in Turkey have been relatively scarce compared with the numerous investigations carried out on research articles, the present study attempts to extend the literature on abstracts by offering a comparison of English journal abstracts in terms of the use of stance adverbs. This study sets out to explore the extent to which native and non-native writers in the social and natural sciences use stance adverbs to construct scientific meaning and a writer's stance in the abstracts of their papers.

\subsection{Stance in Academic Discourse}

The concept of stance has been examined by different researchers under different terms and definitions. Stance 
is defined as "a textual voice”, conveying the attitudinal manner of the writer (Hyland, 2001: p. 176). Similarly, Conrad and Biber (2000) identifies stance as attitudinal stance which reflects the writer's attitude towards an issue, event, or person. Thus, authorial stance presents writers' viewpoints on the components of their work they introduce. Biber (1988) describes stance as "the ways in which an author or speaker overtly expresses attitudes, feelings, judgments, or commitment concerning the message” (p. 204). In other words, linguistic expressions of stance serve to convey how certain the writers feel and also what perspective they take towards a proposition (Biber, 2006). In this respect, Jaffe (2009) points out that taking a stance is observed in every human communication and even establishing a neutral point of view is evidence of stance. Considering the importance of stance, Hyland (2005) proposes a set of concepts in the process of examining stance-taking. These concepts are evidentiality, hedging and boosters.

Research on academic discourse has also shown that soft science and hard science writers interact differently with their readers (Hyland, 1998, 2001). Soft sciences comprise disciplines such as psychology, sociology, linguistics and political sciences and are also called social sciences. Hard sciences, on the other hand, include disciplines such as physics, chemistry and biology and they are labeled as physical or natural sciences. Becher (1989) maintains that knowledge production in soft and hard sciences is carried out differently. While writers in hard sciences reveal objectivity, authors in soft sciences demonstrate greater subjectivity. Thus, there is an impersonalized voice in hard sciences and a personalized stance in the soft sciences.

The ways writers construct their authorial stance in their writings are very highly related to the choice of the stance expressions. For example, author's stance can be established through the use of special classes of verbs (Thompson \& Ye, 1991; Hunston, 1994; Hyland, 2002), adverbials (Biber \& Finegan, 1988; Biber et al., 1999; Conrad \& Biber, 2000), hedges (Hyland, 1996) and metadiscourse features (Hyland, 2002, 2004). Thus, many studies have examined the use of different types of grammatical expressions to determine author's stance inscientific discourse in particularly academic research articles (e.g. Hyland, 1998, 1999, 2005; Hunston \& Thompson, 2000; Conrad \& Biber, 2000; Silver, 2003; Getkham, 2016) and abstracts (e.g. Stotesbury, 2003; Hyland \& Tse, 2005; Ekoç, 2008; Çakır, 2011; Ahmad \& Mehrjooseresht, 2012).

\subsection{Stance Adverbs as the Grammatical Expression of Stance}

Stance adverbs are widely used in academic discourse, and "speakers use stance adverbs to convey their judgments and attitudes, to claim the factual nature of what they are saying, and to mark exactly how they mean their utterances to be understood” (Biber et al., 1999: pp. 766-767). Stance adverbs have been studied exclusively or together with other linguistic expressions within the fields of discourse analysis (Hoye, 1997; Stubbs, 1986) hedging (Hyland, 1998) mitigation (Fraser, 1980; Holmes, 1984) evidentiality (Chafe, 1986) evaluation (Hunston \& Thompson, 2000) appraisal (Martin \& White, 2005). In particular, studies carried out by Biber and Finegan (1988, 1989), and Fraser (1996) among others, have specifically focused on stance adverbs. The classifications proposed in all these studies, however, do not overlap and the adverbs are studied under various labels such as "disjuncts”, “adjuncts”, and "markers”.

The classification of adverbs reflecting stance proposed by Biber (2006) were used to analyze the stance adverbs of academic writers in this study. As shown in Figure 1, Biber et al. (1999) and Biber (2006) distinguish four main types of stance adverbs namely: epistemic adverbs (certainty adverbs, likelihood adverbs), attitude adverbs and style adverbs. Epistemic adverbs present the speaker's comments about the status of information in a proposition and indicate the certainty or doubt. In this group, certainty adverbs denote that the writer commits him/herself to the truth of the proposition expressed in the utterance. Thus, by using acertainty adverb, the writer asserts the truth of the proposition. In contrast, likelihood adverbs are used when the writer makes judgment on the truth value of the proposition and usually indicate a doubt. Attitude adverbs report personal attitudes or feelings. Style adverbs, on the other hand, indicate comments on the communication itself (Biber et al., 1999: pp. 972-975). Style adverbs are employed to comment on the manner of presenting information. They are usually used to strengthen the truth-value of a proposition or claim (Hinkel, 2003).

Even though I have employedthe classification of stance adverbs of Biber et al. (1999) for exploring the linguistic realization of stance, I have departed from it in some respect. First, I look at single word adverbs alone. Secondly, underepistemic adverbs I include also domain adverbs such as biologically, chemically, theoretically. Domain adverbs are also among lexico-grammatical features conveying stance and projecting evaluations. These adverbs reflect comments conveying commitment to the propositional content. By specifying a field within a 


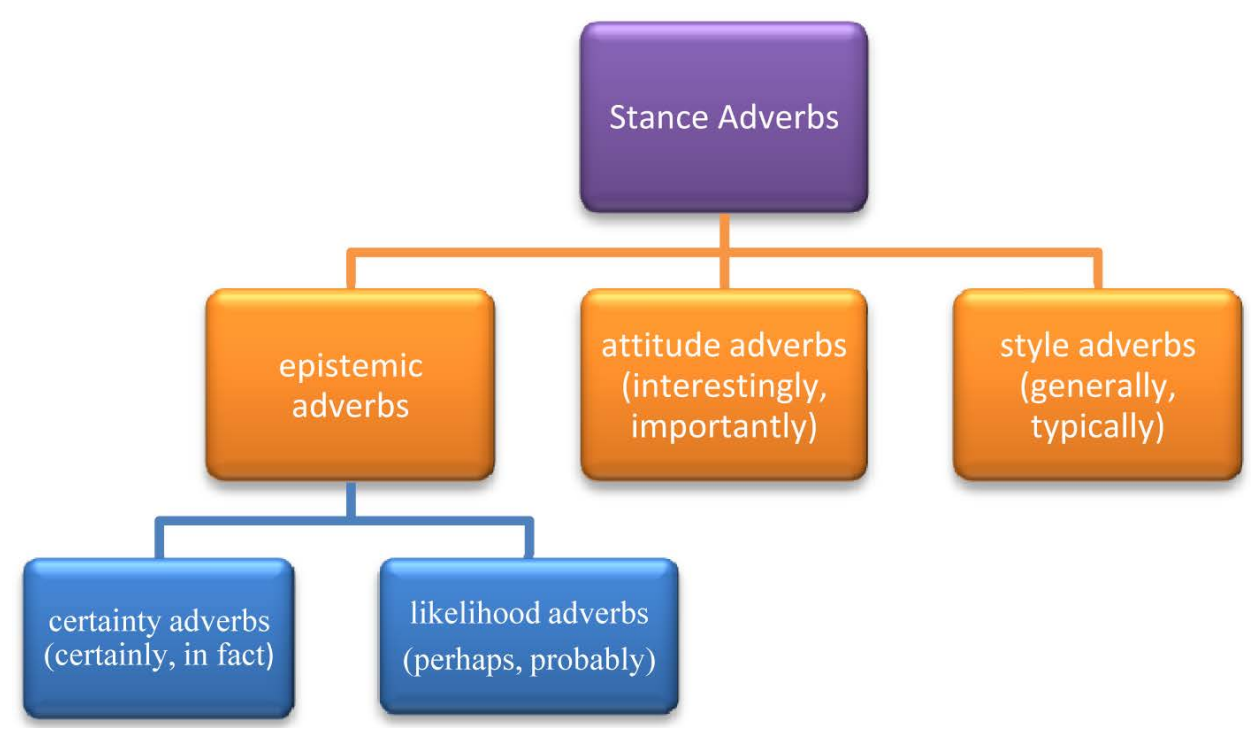

Figure 1. Classification of Stance adverbs (Biber et al., 1999; Biber, 2006).

proposition, the writer signals that the degree of probability of the proposition is the highest (Tseronis, 2009: p. 59).

Within the framework outlined above, this study aims to investigate cultural and genre-based influences on the use of stance adverbs by comparing research article abstracts published in leading Turkish and English journals of linguistics, sociology, psychology, physics, chemistry and biology. Specifically, this paper seeks to answer the following two research questions:

- Are there any similarities/differences in the use of stance adverbs between abstracts written by native and non-native academic writers of English?

- Are there any similarities/differences in the use of stance adverbs in the soft and hard sciences?

\section{Methodology}

\subsection{Construction of Subcorpora}

To address the above research questions, academic article abstracts in six different disciplines were collected. Three of these disciplines represent the soft sciences (sociology, psychology and linguistics) and the other three disciplines represent the hard sciences (physics, chemistry and biology).

Abstracts written in English were randomly compiled from journal articles. Only original research articles were included in the corpus and other contents in the form of other genres, such as editorials, book reviews, short research notes, systematic reviews were disregarded. Abstracts written both by Anglo-American and Turkish writers were selected from journals by professional disciplinary associations. Abstracts by native English writers have been selected where the author is presumed to be a native speaker. They had to be written by scholars based in Anglo-American Universities. Abstracts by Turkish writers had to be written by scholars based in Turkish Universities. All the abstracts were taken from the publication period of 2005-2009.

Two subcorpora were constructed: 1) the E-ORI subcorpus (i.e., English abstracts written by Anglo-American authors published in English journals), and 2) the E-TR subcorpus (i.e., English abstracts written by Turkish authors published in English journals). Thus, the corpora contain English abstracts written by Anglo-American and Turkish writers, which gives us the possibility of comparisons, to determine if the lexico-grammatical choices made by academic writers present variations in the lexico-gramatical choices made by academic writers. Table 1 summarizes descriptive information about the two subcorpora.

In contrastive studies, a similar number of corpus was chosen in order to validate the findings. As illustrated in Table 1, 20 abstracts were randomly selected from six disciplines. Thus, a total number of 240 abstracts were analyzed in this study. Since the number of clauses and size vary across texts, once the abstracts were selected, stance adverbs were counted using the word as a unit of measurement. The number of words in the corpus is given in Table 2. 
Table 1. Descriptive information on the subcorpora.

\begin{tabular}{ccc}
\hline Disciplines & $\begin{array}{c}\text { English Abstracts written by } \\
\text { English writers (native writers) }\end{array}$ & $\begin{array}{c}\text { English Abstracts written by } \\
\text { Turkish writers (non-native writers) }\end{array}$ \\
\hline Sociology & 20 & 20 \\
Psychology & 20 & 20 \\
Linguistics & 20 & 20 \\
Physics & 20 & 20 \\
Chemistry & 20 & 20 \\
Biology & 20 & 20 \\
& 120 & 120 \\
TOTAL & & 240 abstracts \\
\hline
\end{tabular}

Table 2. Number of words in the corpus.

\begin{tabular}{cc}
\hline Abstracts & Number of total words \\
\hline English Abstracts written by & 18,554 \\
English writers & \\
English Abstracts written by & 17,206 \\
Turkish writers & 35,760 \\
Total &
\end{tabular}

\subsection{Data Analysis}

After the selection, abstracts were analyzed in terms of the frequency of stance adverbs in abstracts. Thus, in each abstract, the occurrences of stance adverbs were identified and classified.

Descriptive statistics were used to find the frequencies and averages of authorial stance employed throughout the abstracts. The present study analyzed two subcorpora and to assess the difference between abstracts MINITAB release version 14.12.0 were used in analyzing the data and the critical alpha value was set at 0.05 for this investigation. Significant $p$-values $(p<0.05)$ are highlighted in grey in tables displaying scores.

\section{Results}

\subsection{Total Number of Adverbs}

In the present study, five stance adverb types in abstracts were analyzed in six different disciplines. Figure 2 presents the raw numbers of stance adverbs across abstracts written by Turkish and native academic writers.

Figure 2 illustrates that the use of stance adverbs showed a varying distribution across abstracts. The present corpora have shown no cases of certainty adverbs. Style adverbs are the most frequent stance adverb type in all texts. According to the statistical analysis, there was no significance on the use of likelihood adverbs $(p=0.423>$ $0.05)$, domain adverbs $(p=0.832>0.05)$, attitude adverbs $(p=0.427>0.05)$, and style adverbs $(p=0.373>$ 0.05). However, the difference in the total number of stance adverbs between native and non-native writers was statistically significant $(p=0.001<0.05)$. Native writers used more stance adverbs in their abstracts.

\subsection{Distribution of Adverbs in Hard and Soft Sciences}

The present study also compared abstracts in two different academic communities. Figure 3 gives the findings on the use of the five stance adverbs in soft and hard sciences. The analysis revealed that the abstracts in the soft sciences contained more stance adverbs than those in hard sciences. Both the native and non-native academic writers in soft sciences showed a greater tendency toward the use of style adverbs, followed by the use of attitude adverbs. The highest proportion of stance adverb use from all the texts in the corpus is in the abstracts by native writers in soft sciences.

In abstracts written by Turkish authors, no significance was found on the use of likelihood adverbs ( $p=$ 


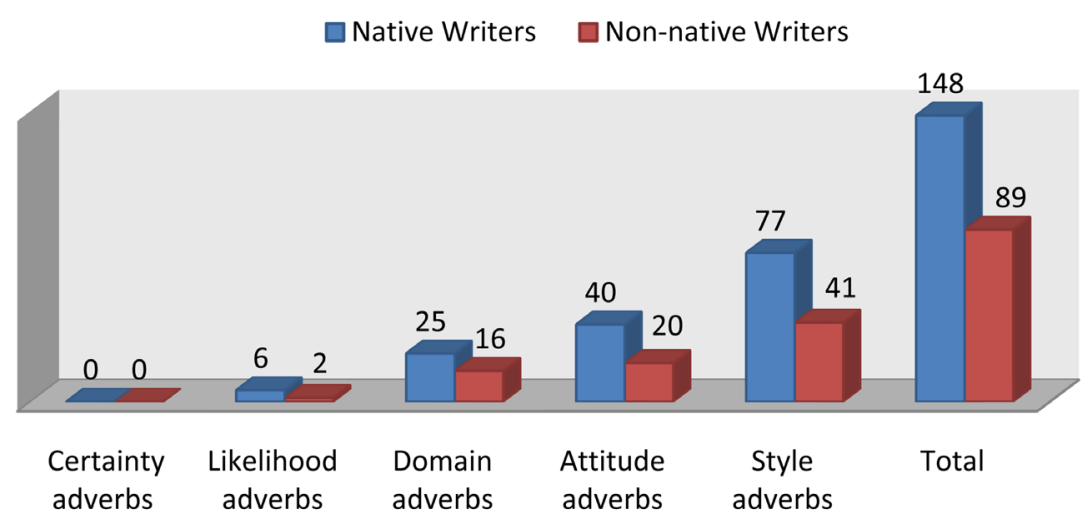

Figure 2. Raw numbers of adverbs used by native and non-native writers.

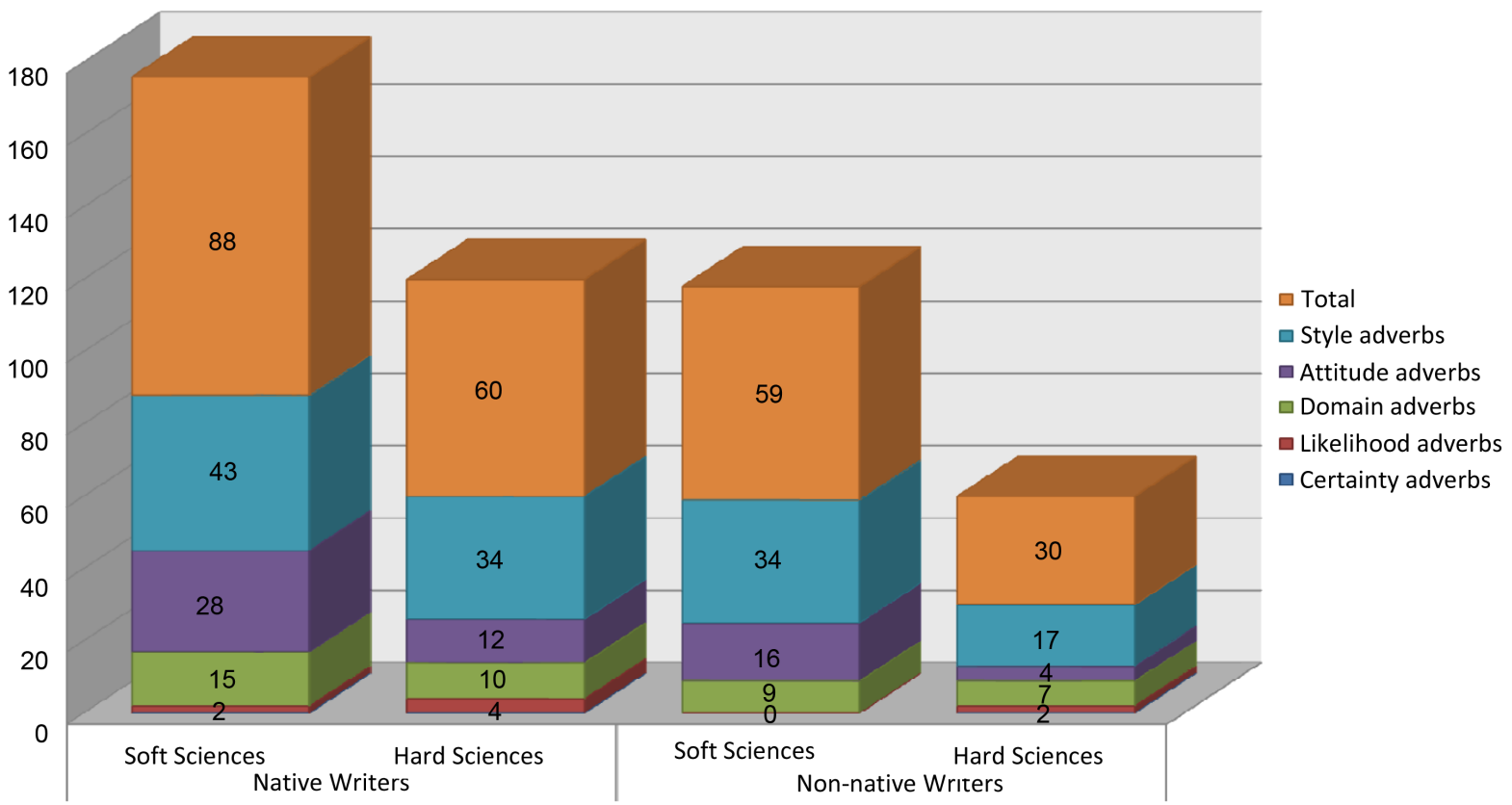

Figure 3. Distribution of stance adverbs across hard and soft sciences.

$0.221>0.05)$, domain adverbs $(p=0.952>0.05)$, attitude adverbs $(p=0.099>0.05)$, and style adverbs $(p=$ $0.349>0.05$ ) in soft and hard sciences, but the difference in the total number of stance adverbs between soft sciences and hard sciences was statistically significant $(p=0.003<0.05)$.

In abstracts of native writers, the difference between likelihood adverbs ( $p=0.143>0.05)$, domain adverbs ( $p=$ $0.371>0.05)$, attitude adverbs $(p=0.104>0.05)$, and style adverbs $(p=0.931>0.05)$ in soft and hard sciences was not significant. Additionally, no significance was found on the total number of stances adverbs between soft and hard sciences $p=0.076>0.05)$.

\subsection{Distribution of Adverbs across Six Disciplines}

Frequency of stance adverbs in each discipline was small, thus formal statistical analysis could not be applied separately on each discipline. However, raw numbers of the frequency of adverbs in each discipline are given in Figure 4 to provide a general picture of how frequently stance adverbs were employed across different disciplines. Disciplinary differences were also found in terms of the distribution of stance adverbs. Disciplines representing the social sciences showed a higher frequency of adverbs. Figure 4 summarizes the results of the frequency distribution of stance adverbs across disciplines. 


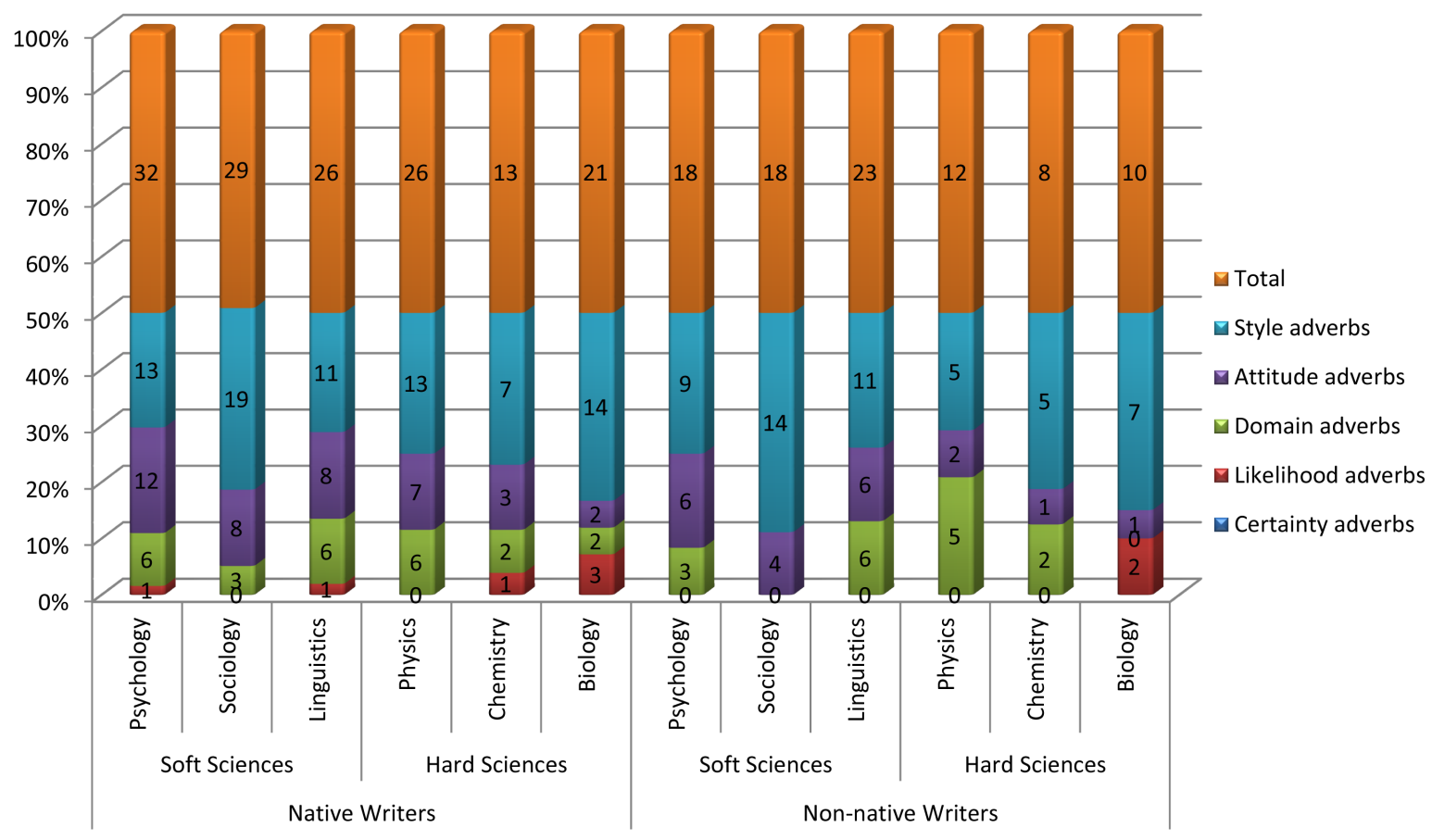

Figure 4. Use of stance adverbs across six disciplines.

\section{Discussion}

The findings of the study revealed a divergence in the use of stance adverbs by native and non-native writers. In response to the first research question, the results indicated that native writers employed stance adverbs, especially style adverbs more than Turkish writers in their abstracts. Style adverbs reflect the comment on the manner of presenting information. They serve to strengthen the truth-value of a proposition or claim (Hinkel, 2003). The findings suggest that Anglo-American writers overall favor the use of style adverbs. Thus, the authorial presence is stronger in abstracts written by native writers. It appears that compared to Anglo-American writers, Turkish writers comment less extensively on their research and they are less likely to emphasize their role as researchers. As a result, these results suggest that Turkish academic writers significantly underused stance adverbs and adopted a less clearly independent stance. Thus, in the light of these findings it can be concluded that native and non-native academic writers employ different strategies in conveying authorial stance in their writings. These results are rather similar to those obtained in previous studies (Melander, Swales, \& Fredrickson, 1997; Martín-Martín, 2002; Hinkel, 2003; Kafes, 2009; Chang \& Schleppegrell, 2011; Çakır, 2011; Çandarlı, 2012; Ülker Eser, 2012; Önder Özdemir \& Longo, 2014; Uysal, 2014; Yağız \& Demir, 2014, 2015) comparing different scientific communities.

In response to the second research question, i.e., whether there were differences in the use of stance adverbs between soft and hard sciences, the results demonstrated that the frequency of stance adverbs was higher in the soft sciences than in hard sciences. This phenomenon seems to indicate that hard sciences and soft sciences use different strategies in presenting scientific meaning. While the hard sciences tends to build knowledge on the basis of experimental observation and evidence, soft sciences seeks for alternative ways to construct scientific knowledge. Thus, in social sciences the academic writer has to draw on different linguistic devices for reasoning and validating his/her point of view. In this respect, disciplines representing the social sciences displayed a higher frequency of stance adverbs. From these results, it can be concluded that there might be different disciplinary norms for using lexico-grammatical features like stance adverbs across disciplines. These findings are in line with previous research (Samraj, 2002; Stotesbury, 2003; Yakhontova, 2006; Çakır, 2011) comparing disciplines.

Overall, the results of the study indicate that differences in the use of stance adverbs reflect culture-bound variations between the Turkish and English writing community. As Yakhontova (2002, 2006) argues, in the English international discourse community, the academic writer tries to "sell” his/her research. Régent (1985) 
and Bachschmidt (1999) on the other hand, point to culture-bound variations by referring to "what” and "why” distinction. In this view, "English abstracts focus on arguing a point" and give emphasis to "why the study is important" to support the argument of the study (Van Bonn \& Swales, 2007: p. 108). However, local scientific communities tend to emphasize facts and inform, that is, "tell" the reader "what the study is about" and the presence of the writer is left implicit (Yakhontova, 2002; Van Bonn \& Swales, 2007). In this respect, as a local discourse community, Turkish scientific language seems to show a tendency to "tell about the study", so the writers does not attempt to promote his/her study; but rather presents his/her data and informs the reader about the study in his/her abstract.

Although the study was able to answer the questions posed, there were some limitations. The first limitation of this study was that the English abstracts of native speakers were randomly chosen from the web sites of the academic journals according to the authors' affiliations and names. It cannot ensure that the English abstracts are written by authentic native speakers of English. Another limitation was that there was no Turkish data to use for comparison. Further research could include the abstracts written in Turkish in order to help cross-reference the results. Increasing the corpus could give researchers a better understanding of author's stance in academic discourse. The next limitation is that this study analyzed abstracts in six disciplines. Further research could be done covering more disciplines. Since academic writing is different across soft and hard sciences, it could be important to understand how academic authors are creating their voice and whether it is appropriate within that discipline. Thus, combining both the Turkish data and a larger data size could create a well-rounded study. The study was also limited in that it focused only on stance adverbs. In order to get a full understanding of how academic writers construct stance in their writing, other lexico-grammatical features of academic discourse should be analyzed. This type of analysis will allow the academic writer to fully understand what the academic discourse is attempting to accomplish through the grammar. Lastly, this study is restricted to analysis of abstracts; therefore the findings of this study may not apply to other genres of academic writing.

Although these limitations show that this research is far from finished, it can help academic writers understand how they construct stance in their writing. Learning the features of academic discourse can help writers understand how language works in any academic setting. This type of awareness would give academic writers a repertoire of voices that they would be able to choose from depending on the type of writing they needed to create and could help them integrate better into the academic community.

\section{Conclusion}

Stance adverbs are important linguistic resources employed by academic writers to interact with the reader and to indicate the degree of certainty about the presented information. Thus, they provide communicative strategies for increasing or reducing the force of statements. This study examined stance adverbs in abstracts written by Turkish and Anglo-American academic writers to determine how academic writers constructed author stance within their scientific community. Furthermore, it also tried to find out whether there were any differences in the soft and hard sciences in the use of stance adverbs.

The overall results obtained in this study suggest that there are obvious differences between the use of stance adverbs by native writers and non-native Turkish writers.

The analysis of abstracts has revealed that native writers employ stance adverbs to emphasize their role as researchers. The comparison of abstracts in the soft and hard sciences found a preference of stance adverbs in the soft sciences. Considering variations in scientific discourse across cultures and disciplines, the results of the study may have some pedagogical implications for academic writing courses.

Although much remains to be done to better understand the linguistic resources that convey stance, this study tried to shed some lights into how non-native and native writers use stance adverbs to construe their stance and comment on their research. Further studies are needed to verify the role of grammatical expressions on authorial stance in academic discourse.

\section{References}

Ahmad, U., \& Mehrjooseresht, M. (2012). Stance Adverbials in Engineering Theses Abstracts. Procedia-Social and Behavioral Sciences, 66, 29-36. http://dx.doi.org/10.1016/j.sbspro.2012.11.244

Akbaş, E. (2012a). Exploring Metadiscourse in Master’s Dissertation Abstracts: Cultural and Linguistic Variations across Postgraduate Writers. International Journal of Applied Linguistics and English Literature, 1, 12-26. 
Akbaş, E. (2012b). Interactional Metadiscourse in Turkish Postgraduates' Academic Texts: A Comparative Study of How They Introduce and Conclude. Journal of English Language Teaching, 2, 35-45.

Akbaş, E. (2014). Are They Discussing in the Same Way? Interactional Metadiscourse in Turkish Writers' Texts. In A. Łyda, \& K. Warchał (Eds.), Occupying Niches: Interculturality, Cross-Culturality and Aculturality in Academic Research (pp. 119-133). London/Berlin: Springer. http://dx.doi.org/10.1007/978-3-319-02526-1 8

Bachschmidt, P. (1999). Construction de l'argumantation dans l'article de recherché en méchanique, differences entre discourse du francophone et de l'anglophone. Asp, 23-26, 197-207. http://dx.doi.org/10.4000/asp.2418

Bayyurt, Y., \& Akbaş, E. (2014). Akademik metinlerde Kaçınma ve Vurgulayıcı Ífadelerin Lisansüstü Öğrenciler Tarafindan Algilanmast ve Kullanılması (Graduate Students' Perception and Use of Hedges and Boosters in Academic Texts). Ulusal Dilbilim Kurultayı Bildirileri. Ankara: Hacettepe Üniversitesi Yayınları.

Bazerman, C. (1985). Physicists Reading Physics—Schema-Laden Purposes and Purpose Laden Schema. Written Communication, 2, 1. http://dx.doi.org/10.1177/0741088385002001001

Bazerman, C. (1988). Shaping Written Knowledge, the Genre and Activity of the Experimental Article in Science. Wisconsin: University of Wisconsin Press.

Becher, T. (1989). Academic Tribes and Territories: Intellectual Inquiry and the Cultures of Disciplines. Milton Keynes: SRHE/Open University Press.

Bhatia, V. K. (1993). Analysing Genre: Language Use in Professional Settings. London: Longman.

Biber, D. (1988). Variation across Speech and Writing. Cambridge: Cambridge University Press. http://dx.doi.org/10.1017/CBO9780511621024

Biber, D. (2006). University Language: A Corpus-Based Study of Spoken and Written Registers. Amsterdam/Philadelphia: John Benjamins. http://dx.doi.org/10.1075/scl.23

Biber, D., \& Finegan, E. (1988). Adverbial Stance Types in English. Discourse Processes, 11, 1-34. http://dx.doi.org/10.1080/01638538809544689

Biber, D., \& Finegan, E. (1989). Styles of Stance in English: Lexical and Grammatical Marking of Evidentiality and Affect. Text, 9, 93-124. http://dx.doi.org/10.1515/text.1.1989.9.1.93

Biber, D., Johansson, S., Leech, G., Conrad, S., \& Finegan, E. (1999). The Longman Grammar of Spoken and Written English. London: Longman.

Breivega, K. R., Dahl, T., \& Fløttum, K. (2002). Traces of Self and Others in Research Articles: A Comparative Pilot Study of English, French and Norwegian Research Articles in Medicine, Economics and Linguistics. Applied Linguistics, 12, 218-239. http://dx.doi.org/10.1111/1473-4192.00032

Çakır, H. (2011). Türkçe ve Ingilizce Bilimsel Makale Özetlerinde Bilgiyi Kurgulama ve Yazar Kimliğini Kodlama Biçimleri (Forms of Constructing Scientific Knowledge and Encoding Writer's Stance in Turkish and English Research Article Abstracts). Unpublished Doctoral Dissertation, İzmir: Dokuz Eylül University.

Çakır, H., \& Fidan, Ö. (2015). A Contrastive Study of the Rhetorical Structure of Turkish and English Research Article Abstracts. In D. Zeyrek, Ç. Sagın Simsek, U. Atas, \& J. Rehbein (Eds.), Ankara Papers in Turkish and Turkic Linguistics (pp. 367-378). Wiesbaden: Harrassowitz Verlag.

Çakır, H., \& Kansu Yetkiner, N. (2012). Information Packaging in Scientific Discourse Across Disciplines and Languages: Explicitation Hypothesis in Translation Studies Revisited. Paper presented at the International Language, Literature and Stylistics Symposium, Edirne: Trakya University.

Çandarlı, D. (2012). A Cross-Cultural Investigation of English and Turkish Research Article Abstracts in Educational Sciences. Studies about Languages, 20, 12-17. http://dx.doi.org/10.5755/j01.sal.0.20.1770

Chafe, W.L. (1986). Evidentiality in English Conversation and Academic Writing. In W. L. Chafe, \& J. Nichols (Eds.), Evidentiality: The Linguistic Coding of Epistemology (pp. 261-272). Norwood, NJ: Ablex.

Chang, P., \& Schleppegrell, M. J. (2011). Taking an Effective Authorial Stance in Academic Writing: Making the Linguistic Resources Explicit for L2 Writers in the Social Sciences. Journal of English for Academic Purposes, 10, 140-151. http://dx.doi.org/10.1016/j.jeap.2011.05.005

Conrad, S., \& Biber, D. (2000). Adverbial Marking of Stance in Speech and Writing. In S. Hunston, \& G. Thompson (Eds.), Evaluation in Text: Authorial Stance and the Construction of Discourse (pp. 56-73). Oxford: Oxford University Press.

Cross, C., \& Oppenheim, C. (2006). A Genre Analysis of Scientific Abstracts. Journal of Documentation, 62, 428-446. http://dx.doi.org/10.1108/00220410610700953

Dahl, T. (2004). Textual Metadiscourse in Research Articles: A Marker of National Culture or of Academic Discipline. Journal of Pragmatics, 36, 1807-1825. http://dx.doi.org/10.1016/j.pragma.2004.05.004

Doyuran, Z. (2009). Conciliation of Knowledge through Hedging in Turkish Scientific Articles. Edebiyat Fakültesi Dergisi/ 
Journal of Faculty of Letters, 26, 85-99.

Duszak, A. (1994). Academic Discourse and Intellectual Styles. Journal of Pragmatics, 21, 291-313. http://dx.doi.org/10.1016/0378-2166(94)90003-5

Ekoç, A. (2008). Analyzing Turkish MA Students' Use of Lexical Hedging Strategies in Theses Abstracts. Unpublished MA Thesis, Istanbul: Istanbul University.

Emeksiz, E. Z. (2009). Passive Clauses in Turkish Academic Discourse. Communication and Argumentation in Public Sphere, 4.

Emeksiz, E. Z. (2015). Stance Taking and Passive Voice in Turkish Academic Discourse. Journal of Language and Linguistic Studies, 11, 13-22.

Fidan, Ö., \& Çakır, H. (2012). The Use of Verbs in Turkish and English Research Article Abstracts. Paper presented at the International Language, Literature and Stylistics Symposium, Edirne: Trakya University.

Fraser, B. (1980). Conversational Mitigation. Journal of Pragmatics, 4, 341-350. http://dx.doi.org/10.1016/0378-2166(80)90029-6

Fraser, B. (1996). Pragmatic Markers. Pragmatics, 6, 167-190. http://dx.doi.org/10.1075/prag.6.2.03fra

Galebiowski, Z. (2009). Prominent Messages in Education and Applied Linguistic Abstracts: How Do Authors Appeal to their Prospective Reader? Journal of Pragmatics, 41, 753-769. http://dx.doi.org/10.1016/j.pragma.2008.10.009

Getkham, K. (2016). Authorial Stance in Thai Students’ Doctoral Dissertation. English Language Education, 9, 80-95. http://dx.doi.org/10.5539/elt.v9n3p80

Graetz, N. (1985). Teaching EFL Students to Extract Structural Information from Abstracts. In J. M. Ulign, \& A. K. Pugh (Eds.), Reading for Professional Purposes: Methods and Materials in Teaching Languages (pp. 123-135). Leuven: Acco.

Halliday, M. A. K. (1994). An Introduction to Functional Grammar. London: Edward Arnold.

Halliday, M. A. K., \& Matthiessen, C. M. I. M. (1999). Construing Experience through Meaning: A Language-Based Approach to Cognition. London: Cassell.

Hinkel, E. (2003). Adverbial Markers and Tone in L1 and L2 Students’ Writing. Journal of Pragmatics, 35, 1049-1068. http://dx.doi.org/10.1016/S0378-2166(02)00133-9

Holmes, J. (1984). Modifying İllocutionary Force. Journal of Pragmatics, 8, 345-365. http://dx.doi.org/10.1016/0378-2166(84)90028-6

Hoye, L. (1997). Adverbs and Modality in English. London: Longman.

Huber, E., \& Uzun, L. S. (2000). Dilbilim alanında Türkçe yazılan bilimsel metinler üzerine gözlemler (Observations on Scientific Texts Written in Turkish in Linguistics). In S. Özsoy, \& E. E. Taylan (Eds.), 2000. XIII. Dilbilim Kurultayı Bildirileri (pp. 201-215). İstanbul: Boğaziçi Ǘniversitesi Yayınları.

Huckin, T. (2001). Abstracting from Abstracts. In M. Hewings (Ed.), Academic Writing in Context: Implications and Applications (pp. 93-103). Birmingham: The University of Birmingham Press.

Hunston, S. (1994). Evaluation and Organization in a Sample of Written Academic Discourse. In M. Coulthard (Ed.), Advances in Written Text Analysis (pp. 191-218). London: Routledge.

Hunston, S., \& Thompson, G. (Eds.) (2000). Evaluation in Text: Authorial Stance and the Construction of Discourse. Oxford: Oxford University Press.

Hyland, K. (1996). Writing without Conviction: Hedging in Science Research Articles. Applied Linguistics, 17, $433-454$. http://dx.doi.org/10.1093/applin/17.4.433

Hyland, K. (1998). Hedging in Scientific Research Articles. Amsterdam: John Benjamins. http://dx.doi.org/10.1075/pbns.54

Hyland, K. (1999). Disciplinary Discourses: Writer Stance in Research Articles. In H. Candlin, \& K. Hyland (Eds.), Writing: Texts, Processes and Practices (pp. 99-121). London: Longman.

Hyland, K. (2000). Disciplinary Discourses. Social Interaction in Academic Writing. London: Longman.

Hyland, K. (2001). Bringing in the Reader: Addressee Features in Academic Writing. Written Communication, 18, 549-574. http://dx.doi.org/10.1177/0741088301018004005

Hyland, K. (2002). Authority and Invisibility: Authorial Identity in Academic Writing. Journal of Pragmatics, 34, 10911112. http://dx.doi.org/10.1016/S0378-2166(02)00035-8

Hyland, K. (2004). Perspectives on Genre. In K. Hyland (Ed.), Genre and Second Language Writing (pp. 24-50). Ann Arbor, MI: The University of Michigan Press.

Hyland, K. (2005). Stance and Engagement: A Model of Interaction in Academic Discourse. Discourse Studies, 7, $173-192$. http://dx.doi.org/10.1177/1461445605050365

Hyland, K., \& Tse, P. (2004). Metadiscourse in Academic Writing: A Reappraisal. Applied Linguistics, 25, 156-177. 
http://dx.doi.org/10.1093/applin/25.2.156

Hyland, K., \& Tse, P. (2005). Hooking the Reader: A Corpus Study of Evaluative That in Abstracts. English for Specific Purposes, 24, 123-139. http://dx.doi.org/10.1016/j.esp.2004.02.002

Jaffe, A. (2009). Stance: Sociolinguistic Perspectives. Oxford: Oxford University Press. http://dx.doi.org/10.1093/acprof:oso/9780195331646.001.0001

Kafes, H. (2009). Authorial Stance in Academic English: Native and Non-Native Academic Speaker Writers' Use of Stance Devices (Modal Verbs) in Research Articles. Unpublished Dissertation, Eskişehir: Anadolu University.

Kafes, H. (2012). Cultural Traces on the Rhetorical Organization of Research Article Abstracts. International Journal on New Trends in Education and Their Implications, 3, 207-220.

Kavanoz, S., \& Şimşek, Ş. (2013). Eğitim Bilimleri Araştırma Makalelerine Tür-Odaklı Yaklaşım: Karşılaştırmalı Çözümleme (A Genre-Based Approach to Research Articles in Educational Sciences: Comparative Analysis). Turkish Studies, 8, 693-710. http://dx.doi.org/10.7827/TurkishStudies.5614

Lorés, R. (2004). On RA Abstracts: From Rhetorical Structure to Thematic Organisation. English for Specific Purposes, 23, 280-302. http://dx.doi.org/10.1016/j.esp.2003.06.001

Martin, J. R., \& White, P. R. R. (2005). The Language of Evaluation. New York: Palgrave.

Martín-Martín P. (2002). A Genre Analysis of English and Spanish Research Paper Abstracts in Experimental Social Sciences. English for Specific Purposes, 22, 25-43. http://dx.doi.org/10.1016/S0889-4906(01)00033-3

Martín-Martín, P., \& Burgess, S. (2004). The Rhetorical Management of Academic Criticism in Research Article Abstracts. Text, 24, 171-195. http://dx.doi.org/10.1515/text.2004.007

Mauranen, A. (1993). Contrastive ESP Rhetoric: Metatext in Finnish-English Economic Texts. English for Specific Purposes, 12, 3-22. http://dx.doi.org/10.1016/0889-4906(93)90024-I

Melander, B., Swales, J. M., \& Fredrickson, K. M. (1997). Journal Abstracts from Three Academic Fields in the United States and Sweden: National or Disciplinary Proclivities? In A. Duszak (Ed.), Culture and Styles of Academic Discourse (pp. 251-272). Berlin: Mouton De Gruyter. http://dx.doi.org/10.1515/9783110821048.251

Moreno, A. (2004). Retrospective Labelling in Premise-Conclusion Metatext: An English-Spanish Contrastive Study of Research Articles on Business and Economics. Journal of English Academic Purpose, 3, 321-339. http://dx.doi.org/10.1016/j.jeap.2004.07.005

Oktar, L. (1991). Contrastive Analysis of Specific Rhetorical Relations in English and Turkish Expository Paragraph Writing. Unpublished Doctoral Dissertation, Izmir: Ege University.

Önder Özdemir, N., \& Longo, B. (2014). Metadiscourse Use in Thesis Abstracts: A Cross-Cultural Study. Procedia-Social and Behavioral Sciences, 141, 59-63. http://dx.doi.org/10.1016/j.sbspro.2014.05.011

Reeves, C. (2005). The Language of Science. London: Routledge.

Régent. O. (1985). A Comparative Approach to the Learning of Specialized Written Discourse. In P. Riley (Ed.), Discourse and Learning: Paper in Applied Linguistics and Language Learning from the Centre de Recherches et d'Applications Pédagoques en Languages (pp. 105-120). New York: Longman.

Salager-Meyer, F. (1992). A Text-Type and Move Analysis Study of Verb Tense and Modality Distribution in Medical English Abstracts. English for Specific Purposes, 11, 93-113. http://dx.doi.org/10.1016/S0889-4906(05)80002-X

Samraj, B. (2002). Disciplinary Variation in Abstracts: The Case of Wildlife Behaviour and Conservation Biology. In J. Flowerdew (Ed.), Academic Discourse (pp. 40-56). London: Pearson.

Santos, M. B. D. (1996). The Textual Organization of Research Paper Abstracts in Applied Linguistics. Text, 16, 481-499. http://dx.doi.org/10.1515/text.1.1996.16.4.481

Silver, M. (2003). The Stance of Stance: A Critical Look at Ways Stance Is Expressed and Modeled in Academic Discourse. Journal of English for Academic Purposes, 2, 359-374. http://dx.doi.org/10.1016/S1475-1585(03)00051-1

Stotesbury, H. (2003). Evaluation in Research Article Abstracts in the Narrative and Hard Sciences. Journal of English for Academic Purposes, 2, 327-341. http://dx.doi.org/10.1016/S1475-1585(03)00049-3

Stubbs, M. (1986). “A Matter of Prolonged Fieldwork”: Notes towards a Modalgrammar of English. Applied Linguistics, 7 , 1-25. http://dx.doi.org/10.1093/applin/7.1.1

Swales, J. (1990). Genre Analysis: English in Academic and Research Settings. Cambridge: Cambridge University Press.

Swales, J. (2004). Research Genres. Cambridge: Cambridge University Press. http://dx.doi.org/10.1017/CBO9781139524827

Tseronis, A. (2009). Qualifying Standpoints: Stance Adverbs as a Presentational Device for Managing the Burden Proof. Utrecht, The Netherlands: LOT.

Ülker Eser, M. (2012). A Comparative Analysis of Thesis Guidelines and Master Thesis Abstracts Written in English at Uni- 
versities in Turkey and in the USA. Unpublished MA Thesis, Ankara: Middle East Technical University.

Uysal H. H., \& Akpınar, K. D. (2008). Cross-Cultural Differences in Turkish, Japanese and Indian Scholars' Conference Abstracts. The 8th International Language, Literature, and Stylistics Conference, Izmir.

Uysal, H. H. (2012). Argumentation across L1 and L2 Writing: Exploring Cultural Influences and Transfer Issues. VIALVigo International Journal of Applied Linguistics, 9, 133-159.

Uysal, H. H. (2014). A Cross-Cultural Study of Indirectness and Hedging in the Conference Proposals of English NS and NNS Scholars. In A. Łyda, \& K. Warchał (Eds.), Occupying Niches: Interculturality, Cross-Culturality and Aculturality in Academic Research (pp. 179-195). Switzerland: Springer International Publishing. http://dx.doi.org/10.1007/978-3-319-02526-1_12

Uzun, L., \& Huber, E. (2002). Türkçede Bilgi Yapısı ve Bilimsel Metinler (Thematic Structure in Turkish and Scientific Texts). Essen: Die Blaue Eule.

Van Bonn, S., \& Swales, J. M. (2007). English and French Journal Abstracts in the Language Sciences: Three Exploratory Studies. Journal of English for Academic Purposes, 6, 93-108. http://dx.doi.org/10.1016/j.jeap.2007.04.001

Ventola, E. (1994). Abstracts as an Object of Linguistic Study. In S. Cmejrkova, F. Danes, \& E. Havlova (Eds.), Writing vs. Speaking. Language, Text, Discourse, Communication (pp. 333-352). Tübingen: Gunter Narr.

Yağız, O., \& Demir, C. (2014). Hedging Strategies in Academic Discourse: A Comparative Analysis of Turkish Writers and Native Writers of English. Procedia-Social and Behavioral Sciences, 158, 260-268.

Yağız, O., \& Demir, C. (2015). A Comparative Study of Boosting in Academic Texts: A Contrastive Rhetoric. International Journal of English Linguistics, 5, 12-28.

Yakhontova, T. (2002). “Selling” or “Telling”? The Issue of Cultural Variation in Research Genres. In J. Flowerdew (Ed.), Academic Discourse (pp. 216-232). Harlow: Pearson Education.

Yakhontova, T. (2006). Cultural and Disciplinary Variation in Academic Discourse: The Issue of Influencing Factors. Journal of English for Academic Purposes, 5, 153-167. http://dx.doi.org/10.1016/j.jeap.2006.03.002

Yarar, E. (2001). Bilimsel araştırma makalelerindeki 'giriş bölümleri'nin söylem yapıları. In XIV. Dilbilim Kurultayı Bildirileri (pp. 110-123). Adana: Çukurova Üniversitesi Yayınları. 